\title{
Teachers' professional development in community campuses of TU: Expectation and responsibility
}

Nani Babu Ghimire

\begin{abstract}
Teachers' professional development programme enables teachers to develop the knowledge and skills they need to address the students' learning. It assists the teachers to improve their instruction for the improvement of student learning achievement and better performance of community campuses. The purpose of this study was to explore the significance of Teachers' Professional Development (TPD) to the teachers of community campus with their expectation, and responsibility. Qualitative case study design was adopted and three teachers were purposively selected from three distinct community campuses of Sindhuli district. Data were collected through semi-structured open-ended interview guidelines. Collected raw data were analysed using thematic analysis. The finding exposed that only teaching in the classroom is not enough for teachers' professional development. Besides, the teachers should participate in training, research work, writing journal article, teachers discussion programmes, learning from media, self/ further study, attending in seminars/work-shops/conferences. TPD helps the teacher to develop professional knowledge, skills, new techniques and technology of teaching. The teachers are themselves supposed to be conscious and initiative for their professional developments.
\end{abstract}

Keywords: Community campus, teachers' professional development, in-service training, self-initiative

\section{Introduction}

Teachers play a fundamental role as front liners in every education system. According to Borg (2003, p. 81), "teachers are active, thinking decision-makers who make instructional choices by drawing on complex practically-oriented, personalized, and context-sensitive networks of knowledge, thoughts, and beliefs." Their role is not simply that of disseminating knowledge or conveying information. It goes far beyond as theirs is the role to create an inspiring learning environment to ensure that all students reach their full potential in all aspects. Ambler (2016, as cited in Rouf \& Mohamed, 2017, p.2) emphasized, "teachers are supposed to be lifelong learners and continuously update themselves."

Teachers' professional development is an emerging issue of the language teaching and learning field. It is believed that one cannot teach appropriately without gaining the teaching strategies or skills, which is directly related to the teachers' professional development. Richards and Farrell (2005, p. 9) write, "Professional development is directed toward both the institutions' goals and the teacher's own personal goals.”According to Hayes (2014, p. 5), " professional 
development is a multi-faced life long experience, which can take place inside or outside the work place". Similarly, Blandford (2000, p. 6) asserts that "professional development refers to the planned activities practised both within and outside schools to develop the professional knowledge, skills, attitudes, and professional staff in schools". Lindborg (2011) mentions that constant change in the working conditions of teachers together with an increased impact of information and communication technologies both lead to a need for teachers to engage in professional development activities.

According to Lambert(2003, p. 22), professional development "includes learning opportunities that can be found in collegial conversations, coaching episodes, shared decision-making groups, reflective journals, parent forums, or other such occasions". Professional development enhances the teachers to develop their knowledge, skills, attitudes, techniques, and strategies to teach their subject effectively. Professional development sharpens the knowledge of teachers and makes them update in their respective subjects. Lindstrom and Speck (2004) define professional development as:

a lifelong, collaborative learning process that nourishes the growth of individuals, teams, and the school through a daily, job-embedded, learner centered, focused approach. It emerges from and meets the learning needs of participants as well as clearly focuses on improving student learning. (p.10)

It is the most important aspect of any teachers and the teachers can get the skills of professional development through pre-service/in-service teacher education programme, training , workshop, seminar, research, self-study, teacher support group, webinar and so on. TPD is usually defined as an attempt designed carefully to develop the teaching skills in teachers. In this sense, teachers' professional development is an attempt to help teachers designed to promote their learning. DaizMaggioli (2003, p. 5) observe as, "the true impact of professional development comes about when efforts are sustained over time, and when support structures exist that allow participants to receive modeling and advice from more experienced peers." TPD is, therefore, a dynamic area of constant change, and as teachers' knowledge and skills are in a constant need of improvement teachers are in need of TPD.

Tribhuvan University is the largest and oldest university in Nepal. There are two categories of campuses in TU: institutional campuses and affiliated as community and private campuses. Institutional campuses are run with complete support of government. The community campuses are run with the support of the community and the government also provide some financial support on the basis of certain criteria. Self finance of owners and students fee is the main source of private campuses. Neither community nor government support such campuses financially. According to Report on Higher Education 2015/16 A.D. Nepal (2017):

In the year 2015/16, there are altogether 1407 higher education campuses, 98 constituent (6.97 percent) campuses, 777 private (55.22 percent) and 532 community ( 37.81 percent) campuses. TU is the largest university in terms of the student strength and the number of 
campuses. It has 1,161 campuses (60 constituent and 1,101 affiliated campuses).

It is almost impossible to obtain quality education without the provision of regular professional development of teacher and its implementation without any partiality. There is special provision for teachers of institutional campus for career development on TU. As mentioned in Teachers Staff Service Law 1998 of TU, teachers of constituent, are enjoying the facilities such as paid study leave, research funds, participation in curriculum design and evaluation system, involvement in decision making process, placement on the basis of knowledge skill and ability, opportunity of promotion, reward on the basis of performance, regular training, and opportunity to participate in workshops. As stated in the affiliation letter, each affiliated campus is committed to manage the teachers, physical facilities, and every aspects of needs of academic environment as per the rules and regulations of TU. So, it is expected that there should be equal opportunity of TPD in constituent and affiliated campuses.

TPD programmes such as training, research work, writing journal article, teachers discussion programmes, learning from media, self/further study, attending in seminars/workshops/conferences have been very fundamental for teachers in shaping their professional career and to shape the better future of the students. In this paper, I have tried to explore the significance of TPD to the teachers of community campus with their expectation, and responsibility at Tribhuvan University.

The purpose of this study was to explore the significance of professional development to the teachers of community campus with their expectation and responsibility in community campus in Nepal. Consequently, it addressed the following research questions:

1. How do the teachers perceive the significance of teachers' professional development in community campuses for developing their profession?

2. What expectations do the community campus teachers have from Tribhuvan University for their professional development?

3. How do th ecommunity campus teachers regard their responsibility for professional development at practice level?

\section{Previous Studies}

The professional development of teachers has been considered a long-term process that includes regular opportunities and experiences planned systematically to promote growth and development in the profession which includes formal experiences (such as attending workshops and professional meetings, mentoring etc) and informal experiences (such as reading professional communications, watching television documentaries related to an academic discipline, etc.) and is boarder than 'career development' and 'staff development' (Villegas-Reimers, 2003). So it is considered a long-term process that includes regular opportunities and experiences planned systematically to promote growth and development in profession. 
Atay (2006) has conducted a study on 'Teachers' Professional Development: Partnership in Research' with the aims to find out the impact of the collaborative action research followed by in an inset programme in the competence of professional competence of in-service and pre-service teachers. The study revealed that participating in collaborative research had a positive impact on the professional development of ITs by broadening their perceptions of research, helping them recognize the value of collaboration, and encouraging them to implement new instructional practices. The professional teachers also had the opportunity to master the basic techniques and skills necessary to conduct principled classroom research by "doing" and through the sharing of expertise and experiences.

Through a case study, Nawab (2017) reported that after attending an in-service course, there were some positive changes in the attitude and practices of the trainee teacher in rural Pakistan. However, gradually the teacher lost his or her enthusiasm for various reasons, such as lack of resources and space, time constraint, workload, no encouragement from other teachers, no collaboration and support, and lack of logistic support from education officials; consequently, the class went back to previous practices. Timalsina (2014) studied college-level teachers' concerns and found that numerous facilities provisioned at community campuses of higher education level for TPD. Negi (2016) found out that TPD was essential for better learning output as most of the teachers were trained and they had gained sufficient knowledge on ELT theory including new innovation in ELT but the bitter reality was that most of the teachers could not put their theoretical knowledge into practice.

Studies reviewed above are carried out in Nepal, Pakistan, America and have focused on different aspects of TPD. Many studies have been carried out on TPD of school level, however, little research is available on TPD at higher level. Furthermore, very limited studies have been carried out on TPD in community campuses in Nepal. The present study addresses the gap in the existing literature and as far as the engagement of teachers of community campus in TPD and their perceived needs for their career development.

\section{Methodology}

This study is devoted to examine the importance, expectation, and responsibilities of/ for teachers' professional development in community campuses of TU. I used a qualitative case study research design in this study as Thomas (2011) said that it is progressively popular among researchers. Cousin (2005) opined that the case study method is not aimed to analyse cases, but it is a good way to define cases and to explore a setting in order to understand it. According to Creswell (2013), the case study method "explores a real-life, contemporary bounded system (a case) or multiple bounded systems (cases) over time, through detailed, indepth data collection involving multiple sources of information... and reports a case description and case themes" (p.97).

This research was conducted in Sindhuli district of Nepal. I selected three community campuses of this district for the purpose of data collection. I purposively selected three teachers 
(i.e., one from eachcampus) as a unit of analysis. Initially, the participants were informed about the objective of the study. They were briefed on how their privacy would be preserved (Rouf $\&$ Mohamed, 2017). In reporting the study, the participants' real names have been disclosed in accordance with research ethics.

Data sources include interview and field notes. A set of semi-structured open-ended interview guidelines was prepared as the research tool to elicit the data for the study. One to one individual interviews were conducted with the selected participants using the semi-structured interview guidelines. All the interviews were audiotaped and securely stored for data analysis. Fieldnotes were also taken in the course of data collection.

As the interview was conducted in Nepali, collected excerpts were translated in English by the researcher for data analysis purpose. As cited in Martin and Dismuke (2018), analyses of both field notes and interview transcriptions involved coding processes, margin notes, descriptive and analytic memoing, frequency counts, data displays, and individual narrative summaries (Miles, Huberman, \& Saldana, 2014). Coding for the interview transcripts was done inductively using methods of constant comparison. Descriptive and analytic memos provided further analysis ( as cited in Martin and Dismuke 2018). Collected qualitative data was analyzed thematically. The responses and experiences of the participants were converted into different themes on the basis of the codes derived from coding process .

\section{Results and Discussion}

Teaching means not only teaching by standing in front of the classroom. To do effective teaching, the teacher should be trained as well as up-dated. Regarding the TPD in community campus of TU, I have discussed the ideas collected from my participants during data collection in three global themes.

\section{Significance of Teachers' Professional Development}

Teachers' professional development is an important aspect of the teaching profession. The teachers of the community campus should develop professional qualities and ought to be conscious of developing their academic career. Pokhrel and Behera ( 2016) opined that TPD has been realized a powerful approach to implement child friendly activity based education for education in the twenty first century. Regarding significance of teachers professional developments Participant A expressed his idea as, "TPD is important for us because it helps us to develop professional skills of teaching and extend the area of knowledge. We get information about recently developed modern technology which supports us for effective teaching through it". The story shows that the teachers of community campus give great importance to TPD because it helps them to develop various kinds of professional skills, knowledge, new techniques with modern technology. The teachers can use new ideas and methodologies in the classroom if they are updated through different activities of TPD. Considering this matter Bicaj and Treska (2014) concluded that the issue of the importance of professional development on gaining new 
knowledge and in raising the quality of teaching is considered a necessity of time, because of the dynamic development of technology, and which should occur at any stage and throughout life. They further explained that this happens through gaining new knowledge through the use of new methodologies in the learning process, improving teacher performance in the classroom, encouraging students' critical and logical thinking towards full and attentive understanding, as well as application of competency-based assessment approach.

In the same context Participant B expressed, "It is also useful to develop the creativity of teacher for child centered learning. It is also helpful to address the need and interest of the students. Furthermore, it encourages the teachers to conduct research-based teaching". It is evident from the above excerpt that the teachers can use new innovation in the classroom and they become creative to solve the problems of the students by addressing their need and following researchbased teaching learning strategies. Guskey (2000) claimed that professional development consists of such processes and activities which is designed to enhance the professional knowledge, skills, and attitudes of educators so that they might, in turn, improve the learning of students. In order to improve student achievement, teachers must have a strong understanding of effective researchbased pedagogical practices. Shulman (1986) explained that professional development provides teachers with opportunities to better understand research-based ideas in the areas of content, curricular, and pedagogical knowledge. In a study, Moutafidou, Melliou and Georgopoulou (2012) concluded that most teachers of the sample relate their professional development with educational research since it promotes their ingenuity, creativity, critical thinking, decision making ability and flexibility to respond to changing conditions.

Likewise, Participant $\mathrm{C}$ explained the importance of teachers' professional development as," TPD is important for the teachers to revise and update their knowledge and skills. The teachers can develop assessment skills and select appropriate teaching-learning materials through TPD." Considering this remark, I thought that TPD is the essential aspect for the teachers who are teaching in the community campuses for the reason that it helps them to revise and update their knowledge and teaching skills as well as assessment skills. Darling-Hammond and McLaughlin (1995) view that teacher training and professional development are central mechanisms for the improvement of teachers' content knowledge and their teaching skills and practices in order to meet high educational standards. The teachers can change the teaching style after participating in the training and they can use child-centered pedagogy in the classroom.

\section{Expectations from TU for Teacher's Professional Development}

The teachers have their own expectations for teacher's professional development from TU. There is a great role of TU for teachers' professional development as it is the university which has given affiliation to community campuses. Here, I have gathered expectations of three participants for TPD from TU. Regarding this context, Participant A mentioned, "TU needs to organize training, conference, seminar, workshop, orientation and visiting programmes on 
different subjects and issues inviting the teachers of community campuses in which they can learn new knowledge and skills in their own subjects". This account emphasizes that there is a huge role of TU for the TPD of community campuses. It should organize subject wise teachers' training time and again. Similarly, it should hold seminars, workshop, and conference on the burning issues of teaching and learning. Sellen (2016) suggested that the average teacher spends 10.5 days per year engaged in courses, workshops, conferences, seminars, observation visits or in-service training for the purposes of continuing professional development.

Echoing a similar perspective, Participant B said, "TU should encourage the teachers to do research by giving opportunities to participate in it. Correspondingly, TU should manage the 'In-Service Training' for the development of teachers' profession". This expression makes it apparent that TU should give an opportunity for the teachers of community campuses to do research on different topics that are related to teaching and learning. TU should start to provide 'In- Service Training' to the teacher of community campuses for their professional development. Birman, Desimon, Porter, and Garet (2000) have shown professional development activities play a key role in teacher preparation and improvement. Moutafidou, Melliou and Georgopoulou (2012) avowed that teachers'positive attitudes regarding the use of research in raising their professional status and power, since through research they acquire professional judgment, develop their own personal theories and broaden their roles and actions. Participant $\mathrm{C}$ expressed, "TU should provide short-term training for teachers through distance mode. Likewise, TU should mange the programs of distance education for further ( $\mathrm{PhD} / \mathrm{MPhil}$ ) study". This statement gives emphasis on distance mode education for short-term training and higher study for the teachers of community campuses from TU. Considering this reality Moon (1997) orated:

Open and distance learning (ODL) systems are making an increasing contribution to the professional development of teachers as school standards and professional standards are inextricably linked, and the need for a teaching force that is flexible and adaptable to the impact of rapidly changing structures of work and leisure (p.8).

\section{Responsibility for Teacher's Professional Development}

Teachers are the main agent of any educational institution. The teachers themselves need to be conscious and take initiative for their professional developments. Regarding the responsibilities for TPD Participant A said," We need to be self-initiative to take part in different kinds of training, workshop and conference in our own subjects by finding out concerned agencies who provide training of TPD for us." This observation shows that the teachers are a change agent and thus they need to be active and aware of their professional development activities. Ben-Peretz, Mendelsona, and Kronb (2003) stated that teachers' expectations determine the understanding of their own role, as the sense of efficiency in the work that teachers experience can also depend on how they see themselves as professionals.

Similarly, Participant B expressed his view on this aspect as, "The agencies such as 
campus chief, campus administration campus management committee(CMC), TU, Dean office, Teachers' professional organizations, University Grants Commission have major responsibility for providing TPD training for teachers." This view shows that the agencies that are working in the field of higher education need to be much more responsible for the professional development of the teachers of community campus in Nepal. Klashnja (2006) stated that almost all European countries provide opportunities for teachers to have access to various forms of professional development while working. In the same way, Participant $\mathrm{C}$ said, "we can observe each other's class, participate in micro/peer teaching and exchange our experience among us. We should be encouraged ourselves for our higher such as MPhil and PhD". Making discussion on the responsibility for TPD Head and Taylor (1997, p. 5) professed as "Teachers have the potential within themselves to become better teachers through deepening their own understanding and awareness of themselves and their learners" This description accounts that the participatory activities of the teachers can assist themselves for their professional development.

\section{Conclusion}

The professional development of teachers is a very broad and diverse field of knowledge. It is regarded as an individual and collective process that should be accomplished in the workplace of the teacher, i.e. the campus. Furthermore, it is looked upon as a contribution to the development of the teacher's professional skills, by means of a variety of both formal and informal experiences. Through TPD programmes the teachers develop professional skills of research-based teaching using modern technology by addressing students' need and interest for child centerd pedagogy. They become updated on assessment skill and use of materials appropriately in the classroom. MacBeath (2005), in his effort to highlight the need for research in teachers' daily practice, stated that raising issues under constant review, looking for proof and critically evaluating data, form core features of the teaching process. As an affiliation provided university TU should have leading role in the TPD by organing short-term training, conference, seminar, workshop, orientation and research oppertunity for the teachers of community campuses Furthermore, it needs to manage the 'In-Service Training' through distance mode for the development of teachers' profession. Being conscious, self initiative and aware the teachers can collaborate with the agencies such as campus management committee (CMC), Dean office TU, University Grants Commission by making them responsible and accountable for their own professional development in community campus.

\section{Implications}

A number of implications related to teacher professional education and development may be drawn from this study. Firstly, TPD makes the teachers enthusiastic and active to participate in professional development programs for developing proper professional knowledge and skills on them to teach effectively in the classroom using appropriate teaching learning aids, devices and assessment tools. It assists the teacher to be identified themselves as qualified and competent teachers in the society and it increases the educational status of the community campus 
nationally and interanationally. Schon (1983) said that teachers should be reflective practitioners who comprehend and evaluate practical situations through research, redefining all the given assumptions, and eventually becoming empowered. The concerned agencies of TPD of community campus need to be sincere and answerable to engage the teachers in the activities of professional development that helps to raise the quality of education in community campus raising the pass percent as well as it supports to decrease the drop out rate of students as well. Timalsina (2014) said that there should be a monitoring mechanism for TPD activities at the organization level and own creative initiation at the institutional level to impart TPD facilities. And, the facilities such as mentoring by senior competent teachers, one to one coaching, university visits, peer learning, subject wise teacher networking, exposures visits, management of E-resources be the options for better activities for TPD of community campuses.

\section{Acknowledgment}

This study was completed with support of University Grants Commission Snothimi, Bhaktapur, Nepal. The author would like to acknowledge the financial assistance of UGC for encouraging him in research activity which is an importamt aspect of professional development of the teachers of community campus.

\section{References}

Ambler, T. B. (2016). The day-to-day work of primary school teachers: A source of professional learning. ProfessionalDevelopment in Education, 42(2), 276- 289. doi: http://dx.doi. org/10.1080/ 19415257.2014.998343

Atay, D. (2006). Teacher professional development: Partnership in research. Teaching English as a Second or Foreign Language.10 (2).Retrieved from: http://www.tesl-ej.org/ej38/a8.pdf Ben-Peretz, M., Mendelsona, N., \&Kronb, F. W. (2003). How teachers in different educational contexts view their roles. Teaching and Teacher Education,19 (2), 277-290. https://doi. org/10.1016/S0742-051X(02)00100-2

Birman, B. F., Desimone, L., Porter, A. C., \& Garet, M. S. (2000). Designing professional development that works. Educational Leadership, 57 (8), 28-33.

Bicaj, A. \&Treska, T.(2014).The effect of teacher professional development in raising the quality of teaching (Pilot Research). Academic Journal of Interdisciplinary Studies, 3 (6), 369378.Doi:10.5901/ajis.2014.v3n6p369

Blandford, S. (2000). Managing professional development in schools. New York:Routledge.

Borg, S. (2003). Teacher cognition in language teaching: A review of research on what language teachers think, know, believe, and do. Language Teaching, 36 (2), 81-109.

Cousin, G. (2005). Case study research. Journal of Geography in Higher Education, 29 (3), 421-427.

Creswell, J. W. (2013). Qualitative inquiry and research design: Choosing among five approaches. Thousand Oaks, CA: Sage.

Darling-Hammond, L., and M. W. McLaughlin. (1995). Policies That support professional development in an era of reform. Phi Delta Kappan76 (8), 597-604. 
Diaz Maggioli, G. (2003). Fulfilling the promise of professional development. IATEFL Issues (August-September).

Guskey, T. (2000). Evaluating professional development. Thousand Oaks, CA: Corwin Press.

Hayes, D. (Eds.). (2014). Innovation in the continuing professional development of English language teachers. BritishCouncil. Retrieved from: https://englishagenda.britishcouncil. org/sites/ec/files/E168\%20Innovations\%20in\%20CPD_FINAL\%20V2\%20web.pdf

Head, K. \& Taylor, P. (1997). Readings in teacher development. Oxford: Heinemann.

Klashnja, S. (2006). Aftesimiprofesionalimesimdhenesve ne vendetevropiane. VanBalkom, W,.Mijatoviq, S. (eds.). Aftesimiprofesional: Pervojangamesimdhenesit per mesimdhenesit. Educator development program.

Lambert, L. (2003). Leadership capacity for lasting school improvement. Alexandria, VA: Association for Supervision and Curriculum Development.

Lindborg, J. O. (2011). Teachers' professional development and ICT: A comparison of four Swedish cases. The university of the Fraser Valley research review 4 (1)

Lindstrom, P., \& Speck, M. (2004). The principal as professional development leader. Thousand Oaks, CA: Corwin Press.

MacBeath, J. (2005). Can teachers learn?, In G. Bagakis (Ed.), Teachers training and professional development (27-41). Athens: Metehmio.

Martin, S. D. \& Dismuke, S. (2018). Investigating differences in teacher practices through a complexity theory lens: The influence of teacher education.Journal of Teacher Education. 69 (1) 22-39. doi: 10.1177/0022487117702573

Mertler, C. (2005). Action research: Teachers as researchers in the classroom. Minneapolis, MN: Sage Communityations, Incorporated.

Miles, M. B., Huberman, A. M., \& Saldana, J. (2014). Qualitative data analysis: A Methods sourcebook (3rd ed.). ThousandOaks, CA: SAGE.

Moon, B. (1997). Open Learning and New Technologies in Teacher Education: New paradigms for development, European Journal of Teacher Education, 20 (1), 7-31.

Moutafidou, A. , Melliou, K. \& Georgopoulou, A. A. (2012). Educational research and teacher development. Social and Behavioral Sciences 31, 156 - 161. doi:10.1016/j.sbspro.2011.12.034

Nawab,A.(2017). Whatdifferencecould in-servicetrainingmake? Insights froma community school of Pakistan. Teacher Development, 21(1), 142-159. doi: 10.1080/13664530.2016.1207094

Negi, J. S. (2016). Teachers' Professional Development to Enhance ELT: Needs Analysis for Developing Teacher Training Program in an EFL Context. Journal of NELTA, 21(1-2), 40-53.

Pokhrel, T. R. \& Behera, S. K.( 2016).Expectations of Teachers from Teachers Professional Development Program in Nepal. American Journal of Educational Research,4,(2),190-194. DOI:10.12691/education-4-2-6

Report on Higher Education 2015/16 A.D. Nepal. (2017). University Grants Commission Sanothimit, Bhaktapur. 
Richards, J. C. \& Farrell, T. S. C. (2005). Professional development for language teachers strategies for teacher learning. New York: Cambridge University Press.

Rouf, A. \& Mohamed, A.R. (2017). Secondary EL teachers' CPD: Present practices and perceived needs. Journal of NELTA 22 (1-2),1-12

Schon, D. A. (1983). The reflective practitioner: How professionals think in action. New York: Basic Books.

Shulman, L.S. (1986). Those who understand: Knowledge growth in teaching. Educational Researcher, 15, 4-14.

Teachers Staff Service Law. (1998). Kathmandu: Tribhuvan University

Thomas, G. (2011). A typology for the case study in social science following a review of definition, discourse, and structure. Qualitative Inquiry, 17 (6), 511- 521. doi. org $/ 10.1177 / 1077800411409884$

Timilsana, B.K. (2014). Teacher professional development at community campuses in Nepal. Retrieved from https://www.researchgate.net/communityation/277306052_

Villegas-Reimers, E. (2003). Teachers' Professional Development: An International review of Literature. Paris: International Institute of Educational Planning. Retrieved from http:// www.unesco.org/iiep on 11 May, 2019.

\section{Appendix-A}

\section{Guideline Questions}

1. What do you mean by teachers' professional development?

2. Would like you to share your idea about the status of teachers' professional development at community campus?

3. What activities are preferred for TPD in community campuses of NEPAL?

4. Do you think teachers' professional development is important for teachers? Why or why not?

5. What expectation do you have from TPD as a teacher of community campus?

6. What do you expect from TU for teachers' professional development?

7. What role a Campus chief, and CMC can play to manage teachers' professional development?

8. Who are responsible for providing teachers' professional development activities in community campuses?

9. How do teachers themselves become responsible fortheir own professional development?

\section{The Author}

Nani Babu Ghimire is a Lecturer at Siddha Jyoti Education Campus Sindhuli, Nepal. He has completed Master's Degree in English Education and English in Arts from Tribhuvan University. He is currently a PhD scholar in English Education at Tribhuvan University. He has published some articles in national journals. He is interested in teacher professional development, medium of instruction, multilingualism and diversity in language education. 